\title{
Youth at Risk: A Global Challenge
}

\author{
Steven W. Edwards, Michelle Rodak \\ Edwards Educational Services, Alexandria, V.A., USA
}

\begin{abstract}
When addressing a complex issue, such as youth at risk, it is essential to acknowledge that youth at risk are the problems not in and of themselves, but rather a symptom of a society that fails to meet the full needs of children and adolescents around the world. In this piece, all citizens, leaders, corporations, and educators are urged to take action and collaborate in building a system that better identifies and mitigates the risk factors youth around the world are facing. Every challenge identified creates an opportunity to do things differently and could ultimately result in mutable outcomes. Failure to attenuate these provocations and lay claim to opportunity would only lead to entropic and long-term consequences.
\end{abstract}

Keywords: global, poverty, youth at risk, youth assets, collaboration, education, corporate social responsibility

\section{Introduction}

The United States has long grappled with issues related to youth at risk. However, current data indicates a troubling trend. For the first time since Harry S. Truman passed legislation creating the National School Lunch Program (NSLP) in 1946, whereupon free and subsidized lunches are provided to qualifying children (children who fall below the poverty level), more than half of school age children are now recipients of this federal program (Federal Education Budget Project, 2014). As the wealthiest nation in the world, that data seems staggering in itself, and it is only one small part of the problem.

Living below the poverty level and receiving a free or subsidized lunch at school is not the only indicator for being "at-risk," and research attests that poverty is a mitigating factor when considering the broader issues.

Education - the enlightenment of youth - is one of the highly valued cornerstones of nearly every society on earth. Rightfully, there is consensus that, for youth to succeed, their minds must be cultivated through education. Though we may initially reference a nation who promises fundamental opportunity and freedoms to its youth, when attempting to explore the perilous decline of youth at risk, the United States certainly does not have a monopoly on the issue. When looking at youth at risk from a global perspective, the data tells a different story.

On a global scale, one billion children live below the poverty level (United Nations International Children's Emergency Fund [UNICEF], 2005). Moreover, poverty is just one of many challenges facing youth. Youth at risk is a multidimensional conundrum that transcends continents, nations, ethnicity, religions, economic levels, and cultures. What furthers the challenges is that a child who is not at risk today may be tomorrow. It is a moving target. The complexity of the issue requires conjoint actions at best, and further underscores the absence of simplistic solutions. It requires deep analysis, not only at the local level, but also on the world stage.

Steven W. Edwards, Ph.D., president and chief executive officer (CEO), Edwards Educational Services. Michelle Rodak, M.A., chief program officer (CPO), Edwards Educational Services. 
There are many pressing global challenges, and they appear regularly in the national and international news: global warming, shortage of fresh water, violent conflicts, terrorism, the list goes on. These issues are alarming in and of themselves, but they are multi-generational as well, necessitating that today's children are adequately prepared to face them in the future. Therefore, mitigating the factors that contribute to youth at risk in the broadest sense of the word becomes essential.

Unfortunately, the failure to understand that youth at risk are not themselves the problems, but rather a symptom of a society that has defaulted in its responsibility to provide for the needs of children and adolescents around the world. This essay is a call for all citizens, leaders, corporations, and educators to take action and coalesce around building a system that reduces and ameliorates the risk factors youth are facing worldwide.

Addressing the challenge, as specified, is not as rudimentary as identifying the root causes. In order to work towards a productive solution, one must examine what indicators contribute to the problem. In the following section, we will clarify what defines youth at risk, the scope of the problem as seen through the lens of educational practices, youth as a valuable asset, and the greater role corporate interests can play when seeking supportive and viable solutions.

\section{Definition of Youth}

What age group does the term "youth" refer to? For the purpose of this essay, the United Nations' classification of youth will be used. The United Nation defines youth when referencing anyone from birth to the age of 25 (United Nations Department of Economic and Social Affairs [UNDESA], n.d.). Why up to the age of 25? According to the American Academy of Child and Adolescent Psychiatry (2011), the brain has not fully matured until this point in a child's development. Until this juncture, reasoning and decision-making can be unsophisticated and immature, at best.

Images of the brain in action indicate that adolescents' brains function much differently than adults relative to decision-making and problem solving. Research has also demonstrated that exposure to drugs and alcohol before birth, head trauma, or other types of brain injury can interfere with normal brain development during adolescence.

Based on the stage of brain development, adolescents are more likely to act on impulse, misread or misinterpret social cues and emotions, get into accidents of all kinds, get involved in conflicts, and engage in potentially dangerous and/or risky behaviors. They are less likely to think before they take act, pause to consider the potential consequences of their actions and behaviors, and modify their dangerous or inappropriate behaviors.

These brain differences do not mean that youth are not capable of making good decisions or cannot tell the difference between right and wrong. Conversely, it does not mean that they should not hold responsible for their actions. An awareness of these differences can assist and guide parents, educators, advocates, and policy makers in understanding, anticipating, and managing the behavior of youth (American Academy of Child and Adolescent Psychiatry, 2011).

Essential to knowing what makes a child or adolescent "tick" is a deep understanding of neurological development, and the absence of this understanding will limit the ability to design effective strategies. There exist multiple factors that can affect healthy brain development and function, and where a person is born and grows up can significantly influence that development for better or worse (Hair, Hanson, Wolfe, \& Pollack, 2015). 


\section{Youth at Risk}

"Youth at risk" can be defined as young people whose background places them "at risk" of future offending or victimization due to environmental, social, and family conditions that hinder their personal development and successful integration into the economy and society (United Nations Human Settlements Programme [UN-HABITAT], 2003). Despite various definitions of youth at risk, there are consistent key identifiers associated with the term.

Environmental, social, and family factors play a predominant role in contributing to or detracting from a child's well-being and healthy development. As referenced in the opening section, economic conditions and living in poverty have historically been contributing factors to placing youth at higher risk (American Psychological Association, 2015). More prevalent, however, is youth that are exposed to multiple factors, which only magnifies the risk.

Viewing the definition through a global lens, despite the consistency of the mitigating circumstances, the depth and scope may vary. For example, a child living below the poverty level in a major city in the United States is not comparable to a child living in poverty in New Delhi, India. Neither is good, but the conditions and circumstances are vastly different. Therefore, although the risk factors may be congruent, the conditions are often dissimilar.

\section{Globalization, Education, and the New Economy}

Today's youth are among the largest peer group in history. There is a "global youth bulge" that encompasses 1.2 billion young people (International Youth Foundation, 2012). This group of young people (up to the age of 25 years old) is currently ill-prepared socially, intellectually, and economically to meet the challenges of a rapidly changing globalized world (Boss, 2012). Turning the tide requires early and ongoing analysis and intervention. Prevention is equally as important, if not more important. If effective prevention initiatives and practices are in place, the need for intervention can be significantly reduced.

The term "globalization" describes changes in global economics affecting production, consumption, and investment (Stromquist, 2002). In a world where people can readily and easily communicate across nations, where boundaries are eroded due to a consistent flow of capital and information, "the world is indeed one global village" (National Commission on Excellence in Education, 1983). In order to be successful, people need to view their global neighbors as potential collaborators and customers, rather than enemies or competitors.

Although, on the surface, it appears as though globalization only moves people closer together, it also simultaneously widens divisions between them as well. A globalized economy favors educated and creative entrepreneurs. This results in jobs and opportunities created at the very top and at the very bottom (Auerswald, 2012), with less of a demand for mid-level workers. Then, how can youth, in developing countries, be expected to compete?

To achieve this sort of global prosperity, the educational system must help youth develop the knowledge and skills needed to live and work across cultural and national borders as global citizens (Zhao, 2015). A different educational paradigm must be in place to facilitate this shift to a new, global economy, as cited in Suarez (2007):

The skills, sensibilities, and competencies needed for identifying, analyzing, and solving problems from multiple perspectives will require nurturing students who are curious and cognitively flexible, can tolerate ambiguity, and can 
synthesize knowledge within and across disciplines. They will need the cultural sophistication to empathize with their peers, who will likely be of different racial, religious, linguistic, and social origins. They will need to be able to learn with and from them, to work collaboratively and communicate effectively in groups made up of diverse individuals. An education for globalization should aim at nothing more nor less than to educate "the whole child for the whole world. (p. 19)

Many experts like Brad Smith, executive vice president and general counsel for Microsoft, also point to high quality education as an essential component of a comprehensive prevention and intervention platform (as cited in Boss, 2012). Smith notes that at present, of the 1.2 billion youth, $44 \%$ spend their lives with the equivalent of an 8 th grade or lower education.

Education needs to be understood in the broadest sense of the word. Too often, when "education" is mentioned, people have a vision of youth sitting in a classroom with rows of desks and a teacher lecturing. Regardless if "education" takes place in the developed world or in the developing world, the visual is pretty much the same. A traditional education alone will not render the results required. Education must be viewed from a much broader and deeper perspective. Still, millions of children across the globe do not have access to an education and therefore, one of the United Nations' Millennial Goals was to ensure at minimum, a primary education for all children (United Nations, 2013). Education must go beyond academics. Addressing social and emotional learning is just as important, but schools cannot do it alone.

\section{Youth as Social Assets}

The challenge is to move from a mindset of youth at risk to youth as social assets. Often, it is an adult mindset that looks at youth from a deficit perspective rather than from an asset perspective, and perception can influence behavior. All youth who are at risk have skills, and these skills need to be identified and cultivated. By doing this, we can significantly influence their self-esteem and self-efficacy (Dweck, 2006).

Regardless of geographic location, decisions are made for youth unequivocally without their voice. Giving youth a voice in decisions that directly affect them is an essential first step in better understanding and addressing risk factors (Ericson \& Ellett, 2002). There are organizations around the world providing a voice to youth, one of which is youth and European social (YES) work. YES is grounded in a philosophy committed to improving the life chances of vulnerable young people and fostering their inclusion in society. This is but one example. Some organizations may superficially attempt to engage the youth, but it is important to keep in mind that this process is more than just having youth present when making decisions, or having conversations. It is truly about giving them an authentic voice.

\section{The Corporate Role}

The business sector plays an increasing role in youth development, since a youth at risk will potentially evolve to an adult at risk, which affects employability, job and work performance, and the corporate bottom line. Youth who feel disengaged from meaningful employment are more likely to participate in criminal activities (Government Accountability Office, 2008.)

Corporate Social Responsibility (CSR) is an increasingly hot topic in the business world. The World Business Council for Sustainable Development (WBCSD) (Holme \& Watts, 1999) defined CSR as "the continuing commitment by business to contribute to economic development, while improving the quality of life of the workforce and their families, as well as of the community and society at large." The corporate role extends far beyond charity. It requires corporations to take an active role in their communities, nations, and worldwide to better meet the needs of youth. 
At the 2013 World Economic Forum in Switzerland, Chris Nassetta, the chief executive officer (CEO) of Hilton Worldwide, spoke of Hilton's commitment to train millions of youth for competitive jobs in the industry. He said, "We have a tremendous opportunity to prevent a lost generation of young people by helping them acquire the life skills and job training they need to be successful in the workplace, and beyond" (Reese, 2014).

Job development and placement with the possibility for upward mobility is just the beginning. Corporations partnering with youth-serving organizations, such as schools, community youth organizations, and non-government organizations (NGOs), could not only potentially offer a wider array of employment services, but also mental health, education, and childcare services to begin to attack the problem of youth at risk from multiple perspectives.

\section{Final Thoughts}

The issue of youth at risk is a global challenge that surpasses cultures, races, and national borders. However, many view the challenge as a problem with the youth themselves, rather than the institutions and environments, and attempt to solve the problem by building more jails or placing more police officers on the corner. We can and must do better than that.

Through powerful and strategic collaboration, citizens, educators, and corporations can maximize their influence and impact in order to provide today's youth with the resources and support they need to develop into thriving adults. Based on the diversity and complexity of the risk factors identified and the cyclical and recursive nature of their consequences, only a multiindustrial and educational approach will be truly successful in addressing the larger issue of reducing the contributing characteristics of youth at risk. While the subject may appear overwhelming from an at-large perspective, we still must begin by addressing youth at risk from this vantage point, and then deliberately work our way from the systemic network of factors outward. As each factor is addressed and improved upon, the next steps will only become more visible and more manageable to climb.

\section{References}

Adler, R. (2012). Connecting the edges: A report of the 2012 Aspen institute roundtable on institutional innovation. Retrieved August 18, 2015, from http://csreports.aspeninstitute.org/documents/ConnectingEdges-FINAL_0.pdf

American Academy of Child and Adolescent Psychiatry. (2011). The teen brain: Behavior, problem-solving, and decision-making (No. 95) [Fact sheet]. Retrieved July 22, 2015, from http://www.aacap.org/App_Themes/AACAP/docs/facts_for_families/95 _the_teen_brain_behavior_problem_solving_and_decision_making.pdf

American Psychological Association. (2015). Effects of poverty, hunger, and homelessness on children and youth. Retrieved July 22, 2015, from https://www.apa.org/pi/families/poverty.aspx

Auerswald, P. (2012). The coming prosperity: How entrepreneurs are transforming the global economy. New York, N.Y.: Oxford University Press.

Boss, S. (2012, March 28). A call to action: Challenges facing global youth. Retrieved August 17, 2015, from http://www.edutopia.org/blog/global-education-youth-challenges-suzie-boss

Dweck, C. (2006). Mindset: The new psychology of success. New York, N.Y.: Random House.

Ericson, D. P., \& Ellett, F. S. (2002, July 2). The question of the student in educational reform. Education Policy Analysis Archives, 10(31). Retrieved August 17, 2015, from http://epaa.asu.edu/ojs/article/viewFile/310/436

Federal Education Budget Project. (2014). Federal school nutrition programs. Retrieved August 18, 2015, from http://febp.newamerica.net/background-analysis/federal-school-nutrition-programs

Government Accountability Office. (2008, February). Federal action could address some of the challenges faced by local programs that reconnect youth to education and employment. Retrieved August 20, 2015, from http://www.gao.gov/assets/280/272790.pdf 
Hair, N. L., Hanson, J. L., Wolfe, B. L., \& Pollack, S. D. (2015). Association of child poverty, brain development, and academic achievement. JAMA Pediatr, 169(9), 822-829. doi: 10.1001/jamapediatrics.2015.1475

Holme, R., \& Watts. P. (1999). Meeting changing expectations: Corporate social responsibility. Geneva, Switzerland: World Business Council for Sustainable Development (WBCSD). ISBN No.: 2-94-0240-03-5

International Youth Foundation. (2012). Opportunity for action: Preparing youth for 21st century livelihoods. Retrieved August 18, 2015, from http://www.iyfnet.org/sites/default/files/Opportunity_for_Action.pdf

National Commission on Excellence in Education. (1983). A nation at risk: The imperative for educational reform. Retrieved July 22, 2015, from http://datacenter.spps.org/uploads/sotw_a_nation_at_risk_1983.pdf

Reese, W. (2014). Corporate social responsibility central to improving prospects for unemployed youth. Retrieved August 20, 2015, from http://csrpulse.com/corporate-social-responsibility-central-to-improving-prospects-for-unemployed-youth/

Stromquist, N. (2002). Education in a globalized world: The connectivity of economic power, eechnology, and knowledge. Lanham: Rowman \& Littlefield Publishers, Inc..

Suarez, M. (2007). Learning in the global era: International perspectives on globalization and education. Los Angeles: University of California Press.

United Nations International Children's Emergency Fund (UNICEF). (2005). The state of the world's children 2005: Childhood under threat. Retrieved August 18, 2015, from http://www.unicef.org/publications/files/SOWC_2005_\%28English\%29.pdf

United Nations. (2013, September). Millennium development goals and beyond 2015 [Fact sheet]. Retrieved July 22, 2015, from http://www.un.org/millenniumgoals/pdf/Goal_2_fs.pdf

United Nations Department of Economic and Social Affairs (UNDESA). (n.d.). Definition of youth [Fact sheet]. Retrieved August 17, 2015, from http://www.un.org/esa/socdev/documents/youth/fact-sheets/youth-definition.pdf

United Nations Human Settlements Programme (UN-HABITAT). (2003). Urban youth-at-risk in Latin America and the Caribbean and the key role of local authorities in addressing youth and crime and promoting citizenship among youth. Retrieved July 22, 2015, from http://ww2.unhabitat.org/ programmes/safercities/uyr.asp

Zhao, Y. (2015). A world at risk: An imperative for a paradigm shift to cultivate 21st century learners. Society, 52(2), 129-135. 